HARDY AND THE SISTER ARTS 
By the same author

THE POEMS OF HENRY CONSTABLE (editor) THE SPENSERIAN POETS 


\title{
HARDY AND THE SISTER ARTS
}

\author{
Joan Grundy
}

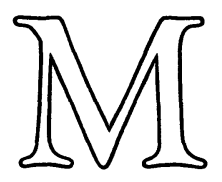


(C) Joan Grundy 1979

Softcover reprint of the hardcover 1st edition 1979

All rights reserved. No part of this publication may be reproduced or transmitted, in any form or by any means, without permission

First published 1979 by THE MACMILLAN PRESS LTD London and Basingstoke Associated companies in Delhi Dublin Hong Kong Johannesburg Lagos Melbourne New York Singapore Tokyo

Typeset in Great Britain by Santype Ltd., Salisbury

\section{British Library Cataloguing in Publication Data}

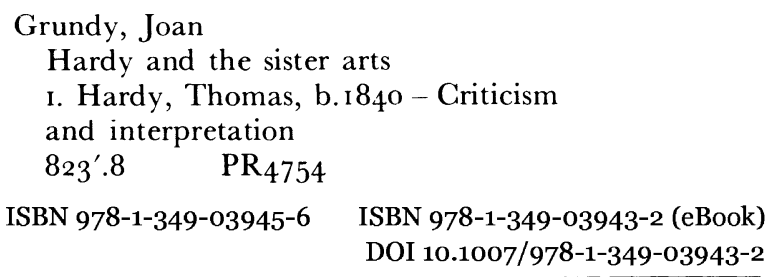

This book is sold subject to the standard conditions of the Net Book Agreement 
To Helen Pilkington

and the memory of Richard 


\section{Contents}

Preface $\quad$ ix

Reference Abbreviations $\quad$ xi

I INTRODUCTION: THE SENTIENT SEER I

2 PICTORIAL ARTS I8

3 THEATRICAL ARTS 70

4 CINEMATIC ARTS

5 MUSIC AND DANCE I 34

6 THE COMPOSITE MUSE $\quad$ I 77

$\begin{array}{ll}\text { Notes } & \text { I90 }\end{array}$

$\begin{array}{ll}\text { Index } & \text { I96 }\end{array}$ 


\section{Preface}

My published work having been hitherto mainly in the Elizabethan field, I feel in publishing a book on Hardy something of a gatecrasher, and a gate-crasher upon an already crowded party. But the fields of literature are subject to no Enclosure Act, and the works of Hardy have been a long-time love of mine. The book began as an exploration: it was written not, at first, because I had something I was burning to say, but rather because there was something I wished to find out. Briefly, I wanted to know what made Hardy so good; even what made Hardy Hardy. I was convinced that the answer lay not, as so many critics were telling me at the time, in either his philosophy, his moral standpoint, or his sociology, but rather in his art, which was still relatively ignored, belittled, or denied to exist. Seeking a more detailed knowledge of the nature of this art, of its roots and affinities, I sought also to understand it in relation to Hardy the writer's most striking single quality, that habit of compassion which in More's Utopia is said to be 'the most human affection of our nature'. Since that time (about nine years ago) the winds of change have blown increasingly in this direction, and works such as J. Hillis Miller's Thomas Hardy, Distance and Desire (1970), Penelope Vigar's The Novels of Thomas Hardy: Illusion and Reality (1974), and Paul Zietlow's Moments of Vision, The Poetry of Thomas Hardy (1974) have confirmed some of my own early findings. My entire enterprise (explained more fully in the Introduction) has been most encouragingly (if unwittingly) endorsed by P. N. Furbank, in his Introduction to the 
New Wessex edition of Tess of the d'Urbervilles, where he presents a view of Hardy's achievement very close in its essential features to my own. More recently, and since my second chapter was written, two admirable treatments of the subject of Hardy's pictorial art have appeared, by F. B. Pinion in his Thomas Hardy: Art and Thought (1977) and by Norman Page in his Thomas Hardy (1977), both treatments differing considerably in scope and intention from mine, as also from each other.

All these, being more substantial than mere straws in the wind, suggest that there is a growing recognition both of the importance of Hardy's artistry, and of how much there is still to be known about it. Writers on Hardy, like diggers for treasure in the Thames mud, may be numerous, but the treasure is not yet exhausted. I hope that I have been able to recover a little more of it.

I should like to record my gratitude to the friends, colleagues, and students who have encouraged me by the interest they have shown in this work, in particular to Professor Barbara Hardy and Dr Katharine J. Worth, who each read some of it in manuscript; to Royal Holloway College, who granted me the two terms of sabbatical leave without which its completion would have been delayed much longer; and to my niece Mrs Helen Pilkington, who devotedly and uncomplainingly prepared the typescript. 


\section{Reference Abbreviations}

References to the novels are to the New Wessex edition (hardback) (London, 1975). Page references for prose and verse are given only where quotations are not readily identifiable through their context. References to The Dynasts specify part, act and scene: thus 2.I.i signifies Part Second, Act I, scene one.

DR Desperate Remedies

UGWT Under the Greenwood Tree

$P B E \quad A$ Pair of Blue Eyes

FFMC Far from the Madding Crowd

$H E \quad$ The Hand of Ethelberta

$R \mathcal{N} \quad$ The Return of the Native

TM The Trumpet-Major

$L \quad$ A Laodicean

TT Two on a Tower

$M C \quad$ The Mayor of Casterbridge

$W \quad$ The Woodlanders

TD Tess of the d'Urbervilles

FO Jude the Obscure

$W B \quad$ The Well-beloved

CP The Complete Poems of Thomas Hardy, ed. James Gibson, New Wessex edition (London, I976)

SS The Short Stories of Thomas Hardy (London, 1928)

Dyn. The Dynasts, in The Poetical Works of Thomas Hardy, vol. II: 'The Dynasts' and 'The Famous Tragedy of the Queen 
xii

Hardy and the Sister Arts

of Cornwall' (London, 1930)

Life F. E. Hardy, The Life of Thomas Hardy (London and New York, 1965) 